\title{
A Comparative Study on the Groebke-Blackburn-Bienaymé Three-Component Reaction Catalyzed by Rare Earth Triflates under Microwave Heating
}

\author{
Gabriela F. D. Santos, ${ }^{a}$ Nicolas S. Anjos, ${ }^{a}$ Miguel M. Gibeli, ${ }^{a}$ Guilherme A. Silva, ${ }^{a}$ \\ Pâmela C. S. Fernandes, ${ }^{a}$ Everton S. C. Fiorentino ${ }^{a}$ and Luiz, S. Longo Jr. ${ }^{\circledR} * a$ \\ ${ }^{a}$ Departamento de Ciências Farmacêuticas, Instituto de Ciências Ambientais, Químicas e Farmacêuticas, \\ Universidade Federal de São Paulo, Rua São Nicolau, 210, 09913-030 Diadema-SP, Brazil
}

\begin{abstract}
Over the last twenty years, the Groebke-Blackburn-Bienaymé (GBB) reaction has been emerged as a powerful tool to access different nitrogen-based heterocycles as privileged scaffolds in medicinal chemistry. This multicomponent reaction is usually catalyzed by ordinary Brønsted or Lewis acid catalysts. Herein, we present a comparative study on the catalytic efficiencies of different rare earth triflates in GBB reactions under microwave heating, involving 2-aminopyridine or 2-aminothiazole, as aminoazole component, and different aldehydes and aliphatic isocyanides. The use of gadolinium(III) triflate as cheaper alternative catalyst for the most commonly used scandium(III) triflate was acknowledged for the first time, and a library of twenty three imidazo[1,2-a]pyridines and imidazo[2,1-b]thiazoles could be obtained in good to excellent yields.
\end{abstract}

Keywords: Groebke-Blackburn-Bienaymé, catalysis, rare earth triflate, multicomponent reaction, gadolinium(III) triflate

\section{Introduction}

The oriented construction of molecular complexity and diversity to access the vastness of chemical space underpins the search for new drugs in modern organic and medicinal chemistry. ${ }^{1-3}$ The importance of understanding the interactions between small organic molecules with biological targets pushes the chemical community towards the development of powerful tools for the rapid and efficient generation of new chemical entities library. Multicomponent reactions (MCR) are referred to as the processes where three or more starting materials are combining together in a one-pot operation to afford a single product, which incorporates into its structure all atoms of the reactants (or most of them). ${ }^{4,5}$ These multibonding-forming transformations are highly atom efficient, generating structural complexity and diversity in a single step from relatively simple and cheap starting materials and catalysts, usually under environmental friendly conditions. ${ }^{6}$

In 1998, three different research groups headed by Katrin Groebke (Switzerland), Christopher Blackburn (United States) and Hugues Bienaymé (France) independently described a three-multicomponent reaction involving amidines (aminoazoles), aldehydes and isocyanides to

*e-mail: luiz.longo@unifesp.br afford several different nitrogen-based heterocycles..$^{7-10}$ Over the last two decades, the chemical community has witnessed many variations of this fascinating reaction, especially related to the aminoazole component used to access different heterocyclic moieties, as well as the experimental conditions (i.e., microwave heating, ultrasound, mechanochemical ball-milling conditions, etc). Several important aspects and applications of the socalled Groebke-Blackburn-Bienaymé (GBB) reaction were extensively reviewed elsewhere. ${ }^{11-15}$

Among all nitrogen-based heterocycles easily obtained by GBB reaction, the imidazo[1,2- $a]$ pyridine has a central role as privileged scaffold with interesting biological properties. ${ }^{16,17}$ For instance, this moiety is present in important drugs, commercially market as anxiolytic (Alpidem), sedative (Saripidem and Necopidem), hypnotic (Zolpidem), anti-ulcer (Zolimidine), and cardiotonic (Olprinone), among others (Figure 1).

The GBB reaction can be catalyzed by simple Brønsted acids, such as $\mathrm{HClO}_{4},{ }^{18-20} p$-toluenesulfonic acid (PTSA), ${ }^{21}$ $\mathrm{AcOH},{ }^{22} \mathrm{HCl},{ }^{23,24}$ as well as $\mathrm{SiO}_{2} / \mathrm{H}_{2} \mathrm{SO}_{4} \cdot{ }^{25}$ Also, GBB reactions catalyzed by heterogeneous catalysts such as succinyl- $\beta$-cyclodextrin, ${ }^{26}$ calix[6]arene- $\mathrm{SO}_{3} \mathrm{H}$ surfactant, ${ }^{27}$ multi-walled carbon nanotubes $/ \mathrm{H}_{2} \mathrm{SO}_{4},{ }^{28}$ cellulose $@ \mathrm{Fe}_{2} \mathrm{O}_{3}$ nanoparticles (NPs), ${ }^{29}$ and fluconazole modified silicacoated magnetite NPs $\left(\mathrm{Fe}_{3} \mathrm{O}_{4} @ \mathrm{SiO}_{2} \text {-Flu }\right)^{30}$ were recently 

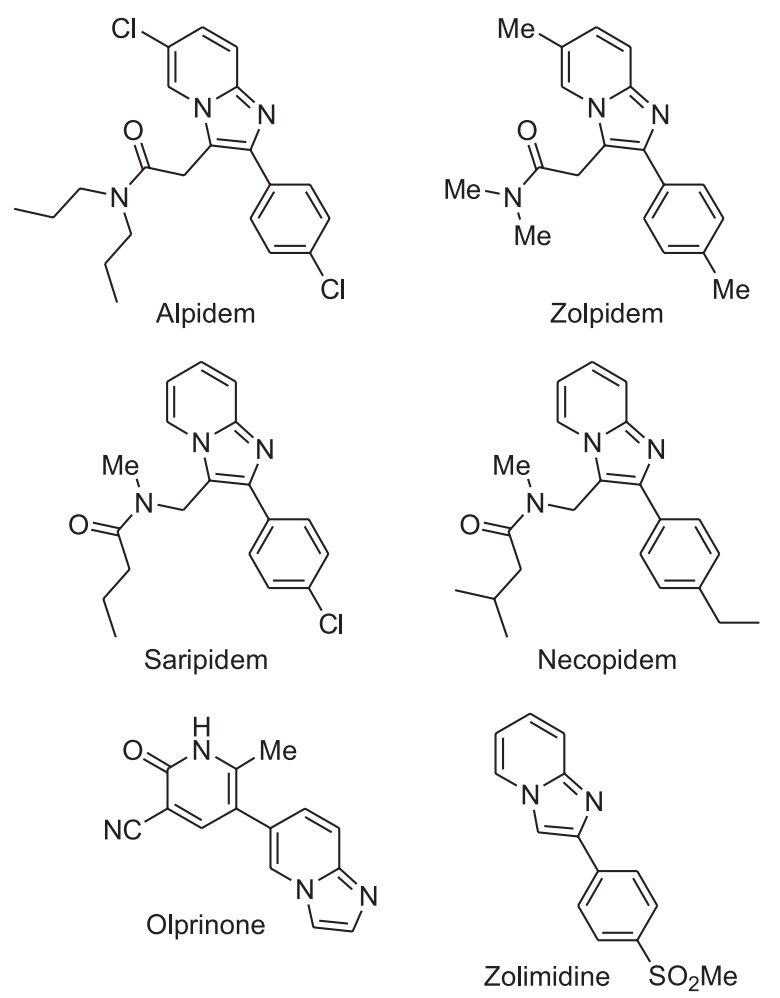

Figure 1. Drugs containing the imidazo[1,2-a]pyridine moiety.

described. However, Lewis acids are the most widely used catalysts for this organic transformation; examples include $\mathrm{InCl}_{3},{ }^{31} \mathrm{BiCl}_{3},{ }^{32,33} \mathrm{RuCl}_{3},{ }^{34} \mathrm{FeCl}_{3},{ }^{35} \mathrm{ZnCl}_{2},{ }^{36} \mathrm{ZrCl}_{4},{ }^{37,38}$ $\mathrm{CeCl}_{3} .7 \mathrm{H}_{2} \mathrm{O},{ }^{39}$ and $\mathrm{LaCl}_{3} .7 \mathrm{H}_{2} \mathrm{O},{ }^{40}$ among others.

From the plethora of possibilities for catalysts, rare earth metal triflates $\left[\operatorname{RE}(\mathrm{OTf})_{3}\right]$ have been emerged as promising water-tolerant and cost-effective Lewis acid catalysts for organic transformations. ${ }^{41-43} \mathrm{RE}(\mathrm{OTf})_{3}$ are relatively safe to handle and commercially available from several chemical suppliers in different purity grades. $\mathrm{Sc}(\mathrm{OTf})_{3}$ generally exhibits higher catalytic activity than its lanthanide(III) counterparts ${ }^{41}$ also being the most expensive and commonly used catalyst for GBB reactions. ${ }^{44-48}$ However, recent studies on the use of $\mathrm{Yb}(\mathrm{OTf})_{3}{ }^{49-51}$ and $\operatorname{In}(\mathrm{OTf})_{3}{ }^{52-55}$ as catalysts for this reaction were also described in the literature. Although they are used in GBB reactions applied to synthesis of different nitrogen-based heterocycles, random generalizations of the scope and limitations of a particular set of reagents prevent a more general conclusion on the utility and reactivity of such catalysts. Herein, we present the evaluation of a series of rare earth triflates as catalysts in the Groebke-Blackburn-Bienaymé reaction for the synthesis of imidazo[1,2-a]pyridines and imidazo[2,1- $b]$ thiazoles. A comparative study of the catalytic activity of selected $\mathrm{RE}(\mathrm{OTf})_{3}$ in model reactions were carefully carried out, and the scope and limitations of the use of relatively inexpensive
gadolinium(III) triflate in Groebke-Blackburn-Bienaymé reactions were demonstrated for the first time.

\section{Results and Discussion}

Our starting point was a control experiment composed of two model reactions between 2-aminopyridine, benzaldehyde and tert-butyl isocyanide or methyl isocyanoacetate in different reaction conditions (Table 1). The screening of the best reaction condition was conducted using $\mathrm{Sc}(\mathrm{OTf})_{3}$, the most common catalyst among the rare earth triflates. Firstly, we carried out the uncatalyzed reactions at room temperature using EtOAc, dichloromethane (DCM) or EtOH as solvents for $72 \mathrm{~h}$, and the imidazo[1,2-a]pyridine $\mathbf{1}$ was obtained in very poor yields (entries 1-3). However, the use of $5.0 \mathrm{~mol} \%$ of $\mathrm{Sc}(\mathrm{OTf})_{3}$ as catalyst in methanol at room temperature for $24 \mathrm{~h}$ promoted an increase in the yield of $\mathbf{1}$ up to $93 \%$ (entry 5). When the reactions were carried out in a sealed tube under microwave heating at optimal temperature value of $150{ }^{\circ} \mathrm{C}$, using $5.0 \mathrm{~mol} \%$ of $\mathrm{Sc}(\mathrm{OTf})_{3}$ in methanol for $30 \mathrm{~min}$, the imidazo[1,2-a]pyridines $\mathbf{1}$ and $\mathbf{2}$ were obtained in 95 and $76 \%$ yield, respectively (entries 7 and 10). Lower catalyst loadings and temperature values led to incomplete reactions with lower conversions and isolated yields observed for both $\mathbf{1}$ and $\mathbf{2}$.

Once we had established the optimal conditions for the $\mathrm{Sc}(\mathrm{OTf})_{3}$-catalyzed Groebke-Blackburn-Bienaymé reaction for the synthesis of imidazo[1,2-a]pyridines $\mathbf{1}$ or $\mathbf{2}$, we next evaluated the catalytic activity of different commercially available metal triflates-M(OTf $)_{3}$, where $\mathrm{M}=\mathrm{Sc}, \mathrm{Y}, \mathrm{La}$, $\mathrm{Eu}, \mathrm{Gd}$ and $\mathrm{Yb}$ (Figure 2). Despite not being rare earth elements, the use of $\operatorname{In}(\mathrm{OTf})_{3}$ and $\mathrm{Bi}(\mathrm{OTf})_{3}$ as Lewis acid catalysts was also investigated. As a general trend, the model reaction using 2-aminopyridine, benzaldehyde and tert-butyl isocyanide for the preparation of $\mathbf{1}$ (60-95\% yield) was more efficiently catalyzed by metal triflates than the reaction with methyl isocyanoacetate to obtain 2 (49-76\% yield). Overall, $\mathrm{Sc}(\mathrm{OTf})_{3}$ was the most active catalyst for both reactions, whilst the lower yields were observed when $\mathrm{Y}(\mathrm{OTf})_{3}$ was used as catalyst. It is noteworthy that the rare earth triflates composed of $\mathrm{La}(\mathrm{OTf})_{3}$ and $\mathrm{Gd}(\mathrm{OTf})_{3}$ showed similar catalytic activity to $\mathrm{Sc}(\mathrm{OTf})_{3}$ in the model reaction for the preparation of $\mathbf{1}$.

The cost of the commercially available rare earth triflates must be taken into account when studying Lewis acid-catalyzed GBB reactions. Although there are some examples of GBB reactions catalyzed by $\mathrm{Yb}(\mathrm{OTf})_{3}{ }^{49-51}$ and $\operatorname{In}(\mathrm{OTf})_{3}{ }^{52-55}$ described elsewhere, the $\mathrm{Sc}(\mathrm{OTf})_{3}$ is still the most commonly used catalyst, ${ }^{4-48}$ despite of being the most expensive salt, whereas $\mathrm{La}(\mathrm{OTf})_{3}$ and $\mathrm{Gd}(\mathrm{OTf})_{3}$ 
Table 1. Control experiments for $\mathrm{RE}(\mathrm{OTf})_{3}$-catalyzed GBB multicomponent model reactions

\begin{tabular}{|c|c|c|c|c|c|}
\hline entry ${ }^{a}$ & Solvent/catalyst & Temperature $/{ }^{\circ} \mathrm{C}$ & time / h & Product & Yield $/ \%$ \\
\hline 1 & EtOAc, no catalyst & $\mathrm{rt}$ & 72 & 1 & traces \\
\hline 2 & $\mathrm{CH}_{2} \mathrm{Cl}_{2}$, no catalyst & $\mathrm{rt}$ & 72 & 1 & traces \\
\hline 3 & EtOH, no catalyst & $\mathrm{rt}$ & 72 & 1 & 12 \\
\hline 4 & $\mathrm{EtOH}, 5.0 \mathrm{~mol} \% \mathrm{Sc}(\mathrm{OTf})_{3}$ & $\mathrm{rt}$ & 24 & 1 & 92 \\
\hline 5 & $\mathrm{MeOH}, 5.0 \mathrm{~mol} \% \mathrm{Sc}(\mathrm{OTf})_{3}$ & $\mathrm{rt}$ & 24 & 1 & 93 \\
\hline 6 & $\mathrm{MeOH}$, no catalyst & 150 & 0.5 & 1 & 13 \\
\hline 7 & $\mathrm{MeOH}, 5.0 \mathrm{~mol} \% \mathrm{Sc}(\mathrm{OTf})_{3}$ & 150 & 0.5 & 1 & 95 \\
\hline 8 & $\mathrm{MeOH}, 2.5 \mathrm{~mol} \% \mathrm{Sc}(\mathrm{OTf})_{3}$ & 150 & 0.5 & 1 & 87 \\
\hline 9 & $\mathrm{MeOH}, 1.0 \mathrm{~mol} \% \mathrm{Sc}(\mathrm{OTf})_{3}$ & 150 & 0.5 & 1 & 75 \\
\hline 10 & $\mathrm{MeOH}, 5.0 \mathrm{~mol} \% \mathrm{Sc}(\mathrm{OTf})_{3}$ & 150 & 0.5 & 2 & 76 \\
\hline 11 & $\mathrm{MeOH}, 5.0 \mathrm{~mol} \% \mathrm{Sc}(\mathrm{OTf})_{3}$ & 150 & 1 & 2 & 70 \\
\hline 12 & $\mathrm{MeOH}, 5.0 \mathrm{~mol} \% \mathrm{Sc}(\mathrm{OTf})_{3}$ & 150 & 2 & 2 & 68 \\
\hline
\end{tabular}

aReagents and conditions: 2-aminopyridine $(0.5 \mathrm{mmol})$, benzaldehyde $(0.5 \mathrm{mmol})$, tert-butyl isocyanide or methyl isocyanoacetate $(0.5 \mathrm{mmol})$, and a

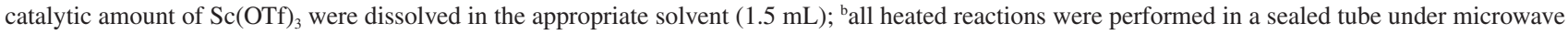



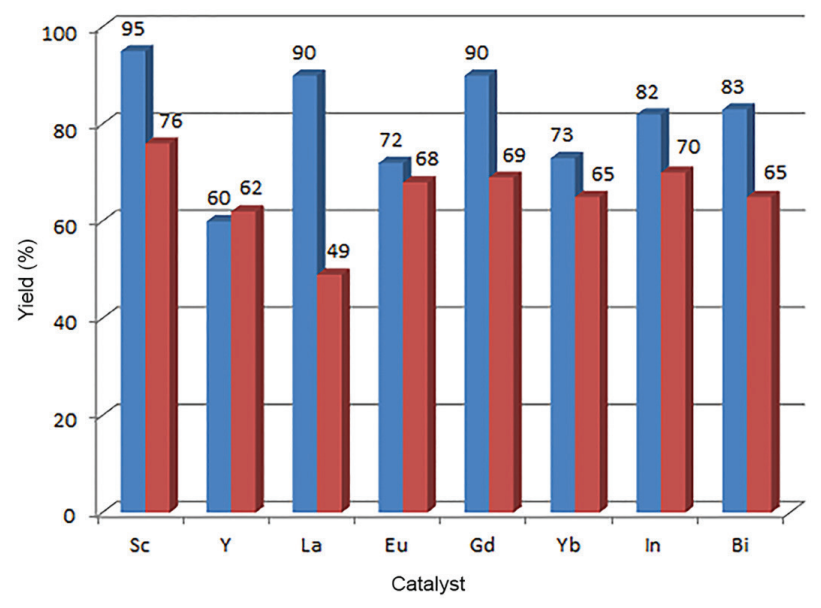

Figure 2. Screening of different metal triflates as catalyst for GBB multicomponent model reactions for imidazo[1,2-a]pyridines $\mathbf{1}$ (blue) and 2 (red). Reagents and conditions: 2-aminopyridine $(0.5 \mathrm{mmol})$, benzaldehyde $(0.5 \mathrm{mmol})$, tert-butyl isocyanide or methyl isocyanoacetate $(0.5 \mathrm{mmol}), \mathrm{M}(\mathrm{OTf})_{3}(5.0 \mathrm{~mol} \%), \mathrm{MeOH}(1.5 \mathrm{~mL}), 150^{\circ} \mathrm{C}, 0.5 \mathrm{~h}$ (microwave; sealed tube).

are usually cheaper alternatives. Also, the reactivity of the carbonyl compound may impact the efficiency of the Lewis acid catalyzed GBB reactions, as the initial steps in the reaction mechanism involve the formation of a Schiff base via nucleophilic attack of the aminoazole component to the carbonyl group of the aldehyde. ${ }^{7,8}$
Keeping these considerations in mind, we next studied the influence of the aldehyde component on the GBB reaction catalyzed by $\mathrm{Sc}(\mathrm{OTf})_{3}, \mathrm{La}(\mathrm{OTf})_{3}$ and $\mathrm{Gd}(\mathrm{OTf})_{3}$. Then, the reaction of a series of para-substituted benzaldehydes with electron withdrawing and electron donating groups $\left(\mathrm{R}^{2}\right)$, using the standard conditions selected in the control experiments earlier discussed, furnished the desired imidazo[1,2-a]pyridines $\mathbf{1 - 6}$ in very similar yields, regardless the rare earth triflate used as catalyst (Table 2). For example, the reaction of 2-aminopyridine, para-anisaldehyde and tert-butyl isocyanide, catalyzed by $5.0 \mathrm{~mol} \%$ of $\mathrm{RE}(\mathrm{OTf})_{3}$ at $150{ }^{\circ} \mathrm{C}$ in $\mathrm{MeOH}$, led to 4 in yields higher than $90 \%$ (entry 4 ). However, it seems that $\mathrm{La}(\mathrm{OTf})_{3}$ is the less efficient catalyst for the reaction of 2-aminopyridine, benzaldehyde and methyl isocyanoacetate (entry 2).

The screening of the catalytic efficiency of $\mathrm{Sc}(\mathrm{OTf})_{3}$, $\mathrm{La}(\mathrm{OTf})_{3}$ and $\mathrm{Gd}(\mathrm{OTf})_{3}$ through the series of aldehydes shown in Table 2 allowed us to determine the good catalytic activity of $\mathrm{Gd}(\mathrm{OTf})_{3}$ in $\mathrm{GBB}$ reactions, as an alternative to the most expensive $\mathrm{Sc}(\mathrm{OTf})_{3}$. Since the pioneering work of Kobayashi and Hachiya ${ }^{56}$ on the use of lanthanide triflates as Lewis acid catalysts in aldol reaction in aqueous media, gadolinium(III) triflate has been investigated as Lewis acid in many different reactions. Some selected examples 
Table 2. Study of the reactivity of the aldehyde component in the GBB reaction catalyzed by different $\mathrm{RE}(\mathrm{OTf})_{3}$

\begin{tabular}{|c|c|c|c|c|c|c|}
\hline \multirow{3}{*}{ entry ${ }^{a}$} & \multirow{3}{*}{ Product } & & $\begin{array}{l}\left(\mathrm{CH}_{3}\right) \\
\mathrm{NO}_{2}\end{array}$ & & 2 & \\
\hline & & \multirow{2}{*}{$\mathrm{R}^{1}$} & \multirow{2}{*}{$\mathrm{R}^{2}$} & \multicolumn{3}{|c|}{ Yield $/ \%$} \\
\hline & & & & $\mathrm{Sc}(\mathrm{OTf})_{3}$ & $\mathrm{La}(\mathrm{OTf})_{3}$ & $\mathrm{Gd}(\mathrm{OTf})_{3}$ \\
\hline 1 & 1 & $\mathrm{C}\left(\mathrm{CH}_{3}\right)_{3}$ & $\mathrm{H}$ & 95 & 90 & 90 \\
\hline 2 & 2 & $\mathrm{CH}_{2} \mathrm{CO}_{2} \mathrm{Me}$ & $\mathrm{H}$ & 76 & 49 & 70 \\
\hline 3 & 3 & $\mathrm{C}\left(\mathrm{CH}_{3}\right)_{3}$ & $\mathrm{NO}_{2}$ & 88 & 88 & 89 \\
\hline 4 & 4 & $\mathrm{C}\left(\mathrm{CH}_{3}\right)_{3}$ & $\mathrm{OMe}$ & 93 & 95 & 94 \\
\hline 5 & 5 & $\mathrm{C}\left(\mathrm{CH}_{3}\right)_{3}$ & $\mathrm{Me}$ & 83 & 82 & 85 \\
\hline 6 & 6 & $\mathrm{C}\left(\mathrm{CH}_{3}\right)_{3}$ & $\mathrm{Br}$ & 90 & 93 & 90 \\
\hline
\end{tabular}

${ }^{a}$ Reagents and conditions: 2-aminopyridine $(0.5 \mathrm{mmol})$, aldehyde $(0.5 \mathrm{mmol})$, tert-butyl isocyanide or methyl isocyanoacetate $(0.5 \mathrm{mmol}), \mathrm{RE}(\mathrm{OTf})_{3}$ $(5.0 \mathrm{~mol} \% ; \mathrm{RE}=\mathrm{Sc}, \mathrm{La}, \mathrm{Gd}), \mathrm{MeOH}(1.5 \mathrm{~mL}), 150^{\circ} \mathrm{C}, 0.5 \mathrm{~h}$ (microwave; sealed tube); bisolated yields.

include the $\mathrm{Gd}(\mathrm{OTf})_{3}$-catalyzed $[3+3]$ cycloaddition of aziridines with $\mathrm{N}, \mathrm{N}$-dialkyl-3-vinylanilines for the stereoselective synthesis of tetrahydroisoquinolines ${ }^{57,58}$ and the 1,5-hydride shift ring closure sequence for the preparation of polycyclic tetrahydroquinolines. ${ }^{59}$ Also interestingly, $\mathrm{Gd}(\mathrm{OTf})_{3}$ was used as Lewis acid co-catalyst to accelerate the oxidative addition of $\mathrm{Ni}^{0}$ catalyst to enones, in a study on the conjugation addition of cyanide to unsaturated ketones. ${ }^{60}$

The catalytic activity of different rare earth triflates correlates well with the lanthanide position in the periodic table, and it can be explained by different properties of the lanthanide element, such as electronic configuration and radius of $\mathrm{Ln}^{3+}$ cation, the rate of the salt hydrolysis as well as water-exchange rate constant (WERC) in innersphere water ligands. In general, the experimental data available for the discontinuity in the lanthanide properties reflect a drop in the product yield when gadolinium-based Lewis acid catalysts are used, for example, in the FriedelCrafts aromatic sulfonylation reaction. ${ }^{61}$ This so-called "gadolinium break" phenomenon is widely discussed in the literature ${ }^{61-63}$ but was not observed for the GBB reactions of this study.

In this scenario, it became obvious to us to evaluate the scope and limitations of the $\operatorname{Gd}(\mathrm{OTf})_{3}$-catalyzed GBB reactions by varying the three components in the set of reagents. In order to explore the great potential to generate molecular diversity applying this protocol, we conducted a substrate scope study with selected aromatic and aliphatic aldehydes, different isocyanides and aminoazoles to construct the structurally diverse chemical library shown in Scheme 1. Our main effort was focused on exploring the use of aromatic aldehydes substituted with electronically diverse groups in different positions. Thus, the reaction of 2-aminopyridine, tert-butyl isocyanide or cyclohexyl isocyanide, and several benzaldehydes catalyzed by $5.0 \mathrm{~mol} \%$ of $\mathrm{Gd}(\mathrm{OTf})_{3}$ in methanol at $150{ }^{\circ} \mathrm{C}$ for 30 min under microwave heating led to the imidazo[1,2-a]pyridines 1-9, 11, 15 and $\mathbf{1 6}$ in good to excellent yields (70-94\%). Similarly, the GBB reaction of 2-aminopyridine with tert-butyl isocyanide (or cyclohexyl isocyanide) and aliphatic aldehydes such as butyraldehyde or isobutyraldehyde led to the expected imidazo[1,2-a]pyridines $\mathbf{1 2 - 1 3}$ and 17-18 in very good yields. At this point, it is worthy to mention that the work up procedure used in our protocol was very simple: after completion of the reaction, the solvent was simply removed under reduced pressure and the crude product was directly purified by column chromatography. In fact, for the most efficient reactions (yields $>90 \%$ ), the desired high pure imidazo[1,2-a]pyridines could be obtained by simple filtration in a small silica gel pad using hexane/EtOAc $(1: 1 \mathrm{v} / \mathrm{v})$ as solvent (to retain the catalyst).

We also embarked our study with 2-aminothiazole as heteroaromatic aminoazole component for the preparation of imidazo[2,1-b]thiazoles. Thus, the model reaction between 2-aminothiazole, tert-butyl isocyanide and benzaldehyde was performed with $5.0 \mathrm{~mol} \%$ of $\mathrm{RE}(\mathrm{OTf})_{3}$ in methanol at $150{ }^{\circ} \mathrm{C}$ using microwave heating (Table 3). The reactions catalyzed by $\mathrm{Sc}(\mathrm{OTf})_{3}, \mathrm{La}(\mathrm{OTf})_{3}$ and $\mathrm{Yb}(\mathrm{OTf})_{3}$ led 


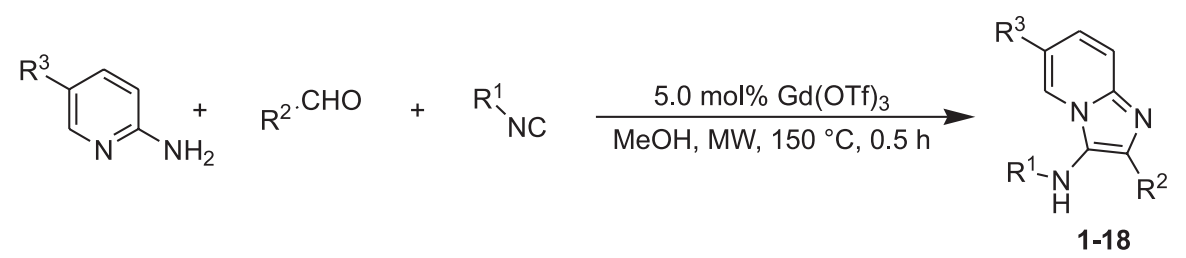<smiles>CC(C)(C)Nc1c(-c2ccccc2)nc2ccccn12</smiles>

$1(90 \%)$<smiles>CC(C)(C)Nc1c(-c2ccc(Br)cc2)nc2ccccn12</smiles>
$6(90 \%)$<smiles>Cc1ccc2nc(-c3ccccc3)c(NC(C)(C)C)n2c1</smiles>

$11(89 \%)$<smiles>COC(=O)CNc1c(-c2ccccc2)nc2ccccn12</smiles>

$2(70 \%)$<smiles>CC(C)(C)Nc1c(-c2ccccc2[N+](=O)[O-])nc2ccccn12</smiles>

$7(90 \%)$<smiles>CCCc1nc2ccccn2c1NC(C)(C)C</smiles>

12 (85\%)<smiles>O=[N+]([O-])c1cccc(-c2nc3ccccn3c2NC2CCCCC2)c1</smiles>

$16(77 \%)$<smiles>CC(C)(C)Nc1c(-c2ccc([N+](=O)[O-])cc2)nc2ccccn12</smiles><smiles>COc1ccc(-c2nc3ccccn3c2NC(C)(C)C)cc1</smiles><smiles>N=c1cccc[nH]1</smiles><smiles>[M]C(NC(C)(C)C)=C(C)c1ccc(C(C)(C)C)cc1</smiles>

$5(85 \%)$<smiles>CC(C)(C)Nc1c(-c2cccc([N+](=O)[O-])c2)nc2ccccn12</smiles><smiles>CC(C)(C)Nc1c(-c2ccc(Cl)c([N+](=O)[O-])c2)nc2ccccn12</smiles><smiles>CC(C)(C)Nc1c(-c2ccco2)nc2ccccn12</smiles>

$8(93 \%)$

$9(87 \%)$

$10(70 \%)$<smiles>CC(C)c1nc2ccccn2c1NC(C)(C)C</smiles>

$13(82 \%)$<smiles>CCCc1nc2ccccn2c1NC1CCCCC1</smiles>

$17(90 \%)$<smiles>c1ccc(-c2nc3ccccn3c2NC2CCCCC2)cc1</smiles>

$14(90 \%)$<smiles>CC(C)c1nc2ccccn2c1NC1CCCCC1</smiles>

$18(92 \%)$<smiles>O=[N+]([O-])c1ccc(-c2nc3ccccn3c2NC2CCCCC2)cc1</smiles>

Scheme 1. Substrate scope: $\mathrm{Gd}(\mathrm{OTf})_{3}$-catalyzed GBB multicomponent reaction for the synthesis of imidazo[1,2-a]pyridines 1-18

to the desired imidazo[2,1-b]thiazole 19 only in moderate yields (entries 1-3). When the reaction was carried out with $5.0 \mathrm{~mol} \%$ of $\mathrm{Gd}(\mathrm{OTf})_{3}$ as catalyst, under similar conditions, the product 19 could be obtained in $68 \%$ yield after $3 \mathrm{~h}$ (entry 5 ; best condition).

Next, we examined the reactivity of different aromatic and aliphatic aldehydes for the preparation of the imidazo[2,1-b]thiazoles 19-23 (Scheme 2). When compared to the imidazo[1,2-a]pyridine series, the yields obtained for the fused-imidazo heterocycles 19-21 were slightly lower. The mechanism of the GBB reaction involves a non-concerted $[4+1]$ cycloaddition of the isocyanide (acting as a vinylidene carbenoid) to the Schiff base formed between the aminoazole and the aldehyde. ${ }^{7}$ Bienaymé and Bouzid ${ }^{8}$ previously observed that electron-poor aminoazoles, such as 2-amino-5nitrothiazole, 2-amino-2-thiazoline or 2-aminoisoxazole, furnished the desired nitrogen-annulated heterocycles in low yields due to the formation of side products that may arise from the addition of nucleophilic solvents (such as methanol) to the Schiff base. In fact, the use of less nucleophilic trifluoroethanol (TFE) as solvent may increase the product yield by preventing the formation of the addition side products. ${ }^{8,64}$ Nevertheless, in our hands, the use of TFE as solvent for the model reaction shown in Table 3 did not result in the increase of the yield observed for imidazo[2,1-b]thiazole $\mathbf{1 9}$. 
Table 3. RE(OTf $)_{3}$-catalyzed model reaction for the synthesis of imidazo[2,1-b]thiazole 19

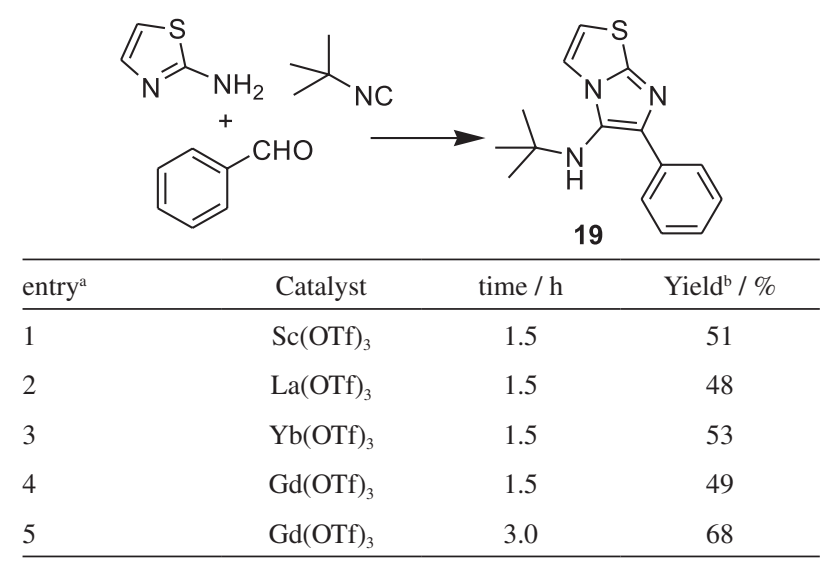

${ }^{a}$ Reagents and conditions: 2 -aminothiazole $(0.5 \mathrm{mmol})$, benzaldehyde $(0.5 \mathrm{mmol})$, tert-butylisocyanide $(0.5 \mathrm{mmol}), \mathrm{RE}(\mathrm{OTf})_{3}(5.0 \mathrm{~mol} \%$; $\mathrm{RE}=\mathrm{Sc}, \mathrm{La}, \mathrm{Gd}, \mathrm{Yb}), \mathrm{MeOH}(1.5 \mathrm{~mL}), 150^{\circ} \mathrm{C}$ (microwave; sealed tube); bisolated yields.

\section{Conclusions}

A systematic study on the use of rare earth triflate as catalyst for Groebke-Blackburn-Bienaymé reactions was presented. As a general conclusion, the catalytic efficiencies of the most common rare earth triflates are undistinguished under the conditions studied so far, i.e., microwave heating at $150{ }^{\circ} \mathrm{C}$ in methanol, despite of the set of reagents used to construct a series of different imidazo[1,2- $a]$ pyridines and imidazo[2,1- $b]$ thiazoles. The aldehyde or aliphatic isocyanide components did not seem to represent major limitations to the method, and the difference in the product yields observed for each individual set of the reagents seems to be related either to the reactivity of aminoazole component and/or to the isolation and purification processes. The current study showed that $\operatorname{Gd}(\mathrm{OTf})_{3}$ can be efficiently used as Lewis acid catalyst for GBB reactions as a cheaper alternative to the most commonly used $\mathrm{Sc}(\mathrm{OTf})_{3}$ salt. The gadolinium(III) triflate-catalyzed GBB reactions under microwave heating exhibited good substrate tolerance (mainly for isocyanide and carbonyl components) and easy work up procedure, allowing the construction of a chemically diverse library of twenty-three nitrogenbased heterocycles. Currently, we are working on the immobilization of rare earth triflate salts into polymeric ionic liquid phases to be used as recyclable heterogeneous catalysts in Groebke-Blackburn-Bienaymé reaction and related multicomponent transformations.

\section{Experimental}

All reagents used in this study were obtained from commercial suppliers and used without further purification, unless otherwise stated. Caution: isocyanides are harmful and toxic reagents! All reactions were carried out inside the fume hoods with appropriate ventilation. Melting points of all compounds were determined using a Buchi 545 MP apparatus and are uncorrected. Column chromatography was performed using silica gel (pore size $60 \AA$, 230-400 mesh). Thin layer chromatography (TLC) analyses were carried out using silica gel plates 60 F254 from Merck $^{\oplus}$; UV-light, vanillin or $p$-anisaldehyde solution were used for visualization. ${ }^{1} \mathrm{H}$ and ${ }^{13} \mathrm{C}$ nuclear magnetic resonance (NMR) spectra were recorded at room temperature on Bruker DPX300, DPX400 or AV400 spectrometers, using $\mathrm{CDCl}_{3}$ as solvent. Chemical shifts $(\delta)$ are expressed in ppm and referenced to the solvent peak; coupling constants are expressed in hertz $(\mathrm{Hz})$. NMR free induction decay (FID) were processed using ACD/ NMR Processor Academic Edition (open access). ${ }^{65}$ High resolution mass spectrometry (HRMS) analyses were carried out using a Bruker MicroTOF 61 spectrometer

$$
\underset{\mathrm{N}}{\mathrm{S}}+\mathrm{R}-\mathrm{CHO}+\mathrm{NC}_{\mathrm{NH}_{2}} \frac{5.0 \mathrm{~mol} \% \mathrm{Gd}(\mathrm{OTf})_{3}}{\mathrm{MeOH}, \mathrm{MW}, 150^{\circ} \mathrm{C}, 3.0 \mathrm{~h}}
$$

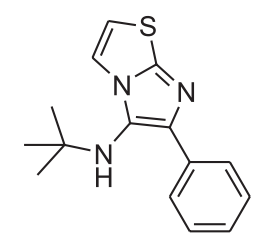

$19(68 \%)$
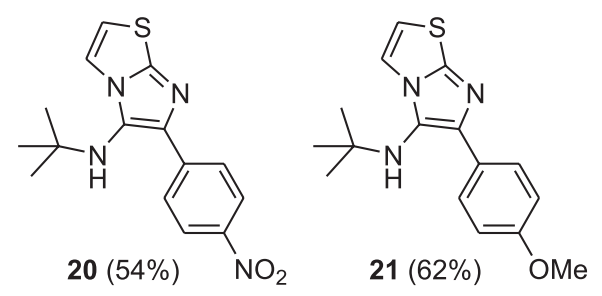

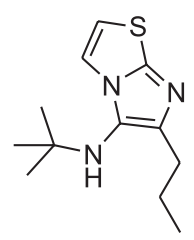

$22(88 \%)$

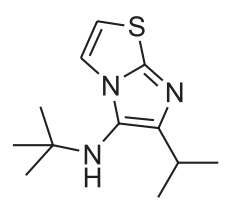

$23(91 \%)$

Scheme 2. Substrate scope: Gd(OTf $)_{3}$-catalyzed GBB multicomponent reaction for the synthesis of imidazo[2,1-b]thiazoles 19-23. 
(electrospray ionization, ESI(+)). Microwave experiments were carried out using MONOWAVE 300 microwave reactor (Anton Paar $^{\circledR}$ ), operating at $2.455 \mathrm{GHz}$ frequency with continuous irradiation power from 0 to $300 \mathrm{~W} ; \mathrm{G} 4$ and G10 borosilicate glass vials (manufacturer design), sealed with Teflon septum, were used for reactions in a $0.5 \mathrm{mmol}$ and $>1.0 \mathrm{mmol}$ scale, respectively. All described reaction times reflect the irradiation time at the set reaction temperature.

General procedure for the metal triflate-catalyzed GroebkeBlackburn-Bienaymé three component reaction for the synthesis of imidazo[1,2-a]pyridines 1 and 2

2-Aminopyridine $(0.5 \mathrm{mmol})$, benzaldehyde $(0.5 \mathrm{mmol})$, tert-butyl isocyanide or methyl isocyanoacetate $(0.5 \mathrm{mmol})$, and the appropriated metal triflate- $\mathrm{M}(\mathrm{OTf})_{3}, \mathrm{M}=\mathrm{Sc}, \mathrm{Y}, \mathrm{La}$, $\mathrm{Eu}, \mathrm{Gd}, \mathrm{Yb}, \mathrm{In}, \mathrm{Bi}(1.0,2.5$ or $5.0 \mathrm{~mol} \%)$-were dissolved in the appropriate solvent $(1.5 \mathrm{~mL}$ of $\mathrm{MeOH}, \mathrm{EtOH}, \mathrm{EtOAc}$ or $\mathrm{CH}_{2} \mathrm{Cl}_{2}$ ). The reaction mixture was stirred at room temperature or at $150{ }^{\circ} \mathrm{C}$ (in this case using microwave heating and sealed tube) during the time specified in Table 1 and Figure 2. Upon completion of the reaction, the solvent was removed under reduced pressure and the crude products were purified by column chromatography using hexane/EtOAc $(1: 1 \mathrm{v} / \mathrm{v})$ as eluent, furnishing the imidazo[1,2- $a$ ]pyridines $\mathbf{1}$ and $\mathbf{2}$ as pure solids in the yields depicted in Table 1 and Figure 2.

The Gd(OTf) ${ }_{3}$-catalyzed Groebke-Blackburn-Bienaymé three component reaction for the synthesis of imidazo[1,2-a]pyridines 1-18 and imidazo[2,1-b]thiazoles 19-23 under microwave heating

In a G4 type microwave vial (Anton Paar design), the 2-aminopyridine or 2-aminothiazole $(0.5 \mathrm{mmol})$, the corresponding aldehyde $(0.5 \mathrm{mmol}$; see Scheme 1$)$, the isocyanide $(0.5 \mathrm{mmol}$; see Scheme 1$)$, and the catalyst $\mathrm{Gd}(\mathrm{OTf})_{3}(5.0 \mathrm{~mol} \%)$ were dissolved in $\mathrm{MeOH}(1.5 \mathrm{~mL})$. The vial was sealed with a Teflon septum (Anton Paar design) and the reaction mixture was stirred $(600 \mathrm{rpm})$ at $150{ }^{\circ} \mathrm{C}$ under microwave heating (variable power) for 30-180 min. Upon completion of the reaction, as indicated by TLC analysis of the crude mixture (eluent hexane/EtOAc 1:1 v/v), the solvent was removed under reduced pressure and the crude products were purified by column chromatography using hexane/EtOAc (gradient 0 to $50 \%$ ) as eluent, furnishing the corresponding imidazo[1,2-a]pyridines $\mathbf{1 - 1 8}$ or imidazo[2,1-b]thiazoles $\mathbf{1 9 - 2 3}$ as pure solids in the yields depicted in Schemes 1 and 2. Please refer to Supplementary Information section for NMR spectra for all compounds.
N-tert-Butyl-2-phenylimidazo[1,2-a]pyridin-3-amine (1) ${ }^{8,66-68}$

CAS 214531-11-6; white solid; mp 161-163 ${ }^{\circ} \mathrm{C}$ (lit: $\left.160-162^{\circ} \mathrm{C}\right) ;{ }^{67,68}{ }^{1} \mathrm{H} \mathrm{NMR}\left(400 \mathrm{MHz}, \mathrm{CDCl}_{3}\right) \delta 1.03(\mathrm{~s}, 9 \mathrm{H})$, 3.14 (br s, H-NH), 6.77 (td, J 6.7, 1.2 Hz, 1H), 7.13 (ddd, $J$ 9.0, 6.7, $1.2 \mathrm{~Hz}, 1 \mathrm{H}), 7.29-7.33(\mathrm{~m}, 1 \mathrm{H}), 7.40-7.45(\mathrm{~m}$, $2 \mathrm{H}), 7.55(\mathrm{td}, J 9.0,1.2 \mathrm{~Hz}, 1 \mathrm{H}), 7.89-7.92(\mathrm{~m}, 2 \mathrm{H}), 8.23$ (dt, $J 6.7,1.2 \mathrm{~Hz}, 1 \mathrm{H}) ;{ }^{13} \mathrm{C}$ NMR $\left(100 \mathrm{MHz}, \mathrm{CDCl}_{3}\right) \delta 30.2$, 56.4, 111.2, 117.3, 123.4, 123.5, 123.9, 127.3, 128.1, 128.2, 135.3, 139.5, 142.0; HRMS (pESI) $\mathrm{m} / 2$, calcd. for $\mathrm{C}_{17} \mathrm{H}_{20} \mathrm{~N}_{3}{ }^{+}$ $[\mathrm{M}+\mathrm{H}]^{+}:$266.1652, found: 266.1656 .

Methyl 2-(2-phenylimidazo[1,2-a]pyridin-3-ylamino)acetate $(2)^{69}$

CAS 879608-97-6; yellowish solid; ' $\mathrm{H}$ NMR $(400 \mathrm{MHz}$, $\left.\mathrm{CDCl}_{3}\right) \delta 3.71(\mathrm{~s}, 3 \mathrm{H}), 3.81(\mathrm{~d}, J 5.3 \mathrm{~Hz}, 2 \mathrm{H}), 3.90(\mathrm{br} \mathrm{s}$, $\mathrm{H}-\mathrm{NH}), 6.3(\mathrm{t}, J 6.8 \mathrm{~Hz}, 1 \mathrm{H}), 7.15-7.19(\mathrm{~m}, 1 \mathrm{H}), 7.28-7.34$ $(\mathrm{m}, 1 \mathrm{H}), 7.44(\mathrm{t}, J 7.8 \mathrm{~Hz}, 2 \mathrm{H}), 7.57(\mathrm{~d}, J 9.0 \mathrm{~Hz}, 1 \mathrm{H})$, 8.00-8.05 (m, 2H), $8.27(\mathrm{~d}, J 6.8 \mathrm{~Hz}, 1 \mathrm{H}) ;{ }^{13} \mathrm{C}$ NMR $\left(100 \mathrm{MHz}, \mathrm{CDCl}_{3}\right) \delta 49.0,52.1,112.1,117.0,122.9$, 124.6, 124.8, 126.9, 127.7, 128.6, 133.3, 135.3, 141.2, 172.1; HRMS (pESI) $m / z$, calcd. for $\mathrm{C}_{16} \mathrm{H}_{16} \mathrm{~N}_{3} \mathrm{O}_{2}{ }^{+}[\mathrm{M}+\mathrm{H}]^{+}$: 282.1237, found: 282.1229 .

N-tert-Butyl-2-(4-nitrophenyl)imidazo[1,2-a]pyridin-3-amine (3)

CAS 2118265-54-4; orange solid; mp 198-200 ${ }^{\circ} \mathrm{C}$; ${ }^{1} \mathrm{H}$ NMR (300 MHz, $\mathrm{CDCl}_{3}$ ) $\delta 1.09$ (s, 9H), 3.04 (br s, H-NH), 6.82 (td, $J 6.8,1.1 \mathrm{~Hz}, 1 \mathrm{H}), 7.19$ (ddd, $J$ 9.0, 6.8, $1.1 \mathrm{~Hz}, 1 \mathrm{H}), 7.55(\mathrm{dt}, J 9.0,1.1 \mathrm{~Hz}, 1 \mathrm{H}), 8.18(\mathrm{dt}, J 6.8$, $1.1 \mathrm{~Hz}, 1 \mathrm{H}), 8.22-8.29(\mathrm{~m}, 4 \mathrm{H}) ;{ }^{13} \mathrm{CNMR}\left(75 \mathrm{MHz}, \mathrm{CDCl}_{3}\right)$ $\delta 30.5,56.8,112.0,117.7,123.4,123.5,124.8,125.0$, 128.4, 137.1, 141.9, 142.5, 146.6; HRMS (pESI) $\mathrm{m} / z$, calcd. for $\mathrm{C}_{17} \mathrm{H}_{19} \mathrm{~N}_{4} \mathrm{O}_{2}{ }^{+}[\mathrm{M}+\mathrm{H}]^{+}:$311.1503, found: 311.1500 .

N-tert-Butyl-2-(4-methoxyphenyl)imidazo[1,2-a]pyridin3-amine (4) ${ }^{36,50,53}$

CAS 518015-55-9; pale yellow solid; mp $130-132{ }^{\circ} \mathrm{C}$ (lit: $\left.138-142^{\circ} \mathrm{C}\right) ;{ }^{50} \mathrm{H}$ NMR $\left(300 \mathrm{MHz}, \mathrm{CDCl}_{3}\right) \delta 1.04$ (s, 9H), 3.06 (br s, H-NH), 3.85 (s, 3H), 6.75 (td, $J$ 6.8, $1.2 \mathrm{~Hz}, 1 \mathrm{H}), 6.94-6.99$ (m, 2H), 7.11 (ddd, $J$ 9.0, 6.8, $1.1 \mathrm{~Hz}, 1 \mathrm{H}), 7.48-7.56(\mathrm{~m}, 1 \mathrm{H}), 7.83-7.88(\mathrm{~m}, 2 \mathrm{H}), 8.20$ (dt, $J 6.8,1.1 \mathrm{~Hz}, 1 \mathrm{H}) ;{ }^{13} \mathrm{C}$ NMR $\left(75 \mathrm{MHz}, \mathrm{CDCl}_{3}\right) \delta 30.3$, 55.2, 56.3, 111.1, 113.6, 117.0, 122.8, 123.3, 123.8, 127.8, 129.3, 139.3, 141.9, 158.9; HRMS (pESI) $\mathrm{m} / \mathrm{z}$, calcd. for $\mathrm{C}_{18} \mathrm{H}_{22} \mathrm{~N}_{3} \mathrm{O}^{+}[\mathrm{M}+\mathrm{H}]^{+}: 296.1757$, found: 296.1756 .

N-tert-Butyl-2-(p-tolyl)imidazo[1,2-a]pyridin-3-amine (5) ${ }^{67,70}$

CAS 518015-60-6; white solid; mp 149-152 ${ }^{\circ} \mathrm{C}$ (lit: $\left.149-150{ }^{\circ} \mathrm{C}\right) .{ }^{67,70}{ }^{1} \mathrm{H}$ NMR $\left(300 \mathrm{MHz}, \mathrm{CDCl}_{3}\right) \delta 1.04(\mathrm{~s}$, 9H), 2.38 (s, 3H), 3.10 (br s, H-NH), $6.74(\mathrm{td}, J 6.8,1.1 \mathrm{~Hz}$, $1 \mathrm{H}), 7.11(\mathrm{ddd}, J 9.0,6.8,1.1 \mathrm{~Hz}, 1 \mathrm{H}), 7.19-7.27(\mathrm{~m}, 2 \mathrm{H})$, 
$7.53(\mathrm{dt}, J$ 9.0, $1.1 \mathrm{~Hz}, 1 \mathrm{H}), 7.76-7.83(\mathrm{~m}, 2 \mathrm{H}), 8.21(\mathrm{dt}$, $J$ 6.8, $1.1 \mathrm{~Hz}, 1 \mathrm{H}) ;{ }^{13} \mathrm{C} \mathrm{NMR}\left(75 \mathrm{MHz}, \mathrm{CDCl}_{3}\right) \delta 21.3$, 30.3, 56.4, 111.1, 117.2, 123.2, 123.4, 123.8, 127.9, 128.9, 132.3, 137.0, 139.5, 141.9; HRMS (pESI) $\mathrm{m} / 2$, calcd. for $\mathrm{C}_{18} \mathrm{H}_{22} \mathrm{~N}_{3}{ }^{+}[\mathrm{M}+\mathrm{H}]^{+}: 280.1802$, found: 280.1812 .

N-tert-Butyl-2-(4-bromophenyl)imidazo[1,2-a]pyridin3-amine $(6)^{67,71}$

CAS 1370642-49-1; white solid; mp $144-146{ }^{\circ} \mathrm{C}$ (lit: 146-147 $\left.{ }^{\circ} \mathrm{C}\right) ;{ }^{67,71}{ }^{1} \mathrm{H}$ NMR (400 MHz, $\left.\mathrm{CDCl}_{3}\right) \delta 1.06$ (s, 9H), 3.00 (br s, H-NH), 6.79 (td, $J$ 6.7, $1.1 \mathrm{~Hz}, 1 \mathrm{H}), 7.15$ (ddd, $J$ 9.0, 6.7, $1.1 \mathrm{~Hz}, 1 \mathrm{H}), 7.50-7.59$ (m, 3H), 7.84-7.90 $(\mathrm{m}, 2 \mathrm{H}), 8.20$ (dt, $J 6.7,1.1 \mathrm{~Hz}, 1 \mathrm{H}) ;{ }^{13} \mathrm{C}$ NMR $(75 \mathrm{MHz}$, $\left.\mathrm{CDCl}_{3}\right) \delta 30.4,36.5,111.5,117.4,121.3,123.4,123.5,124.3$, 129.6, 131.4, 134.2, 138.4, 142.1; HRMS (pESI) $\mathrm{m} / \mathrm{z}$, calcd. for $\mathrm{C}_{17} \mathrm{H}_{19} \mathrm{BrN}_{3}{ }^{+}[\mathrm{M}+\mathrm{H}]^{+}:$344.0757, found: 344.0758 .

\section{N-tert-Butyl-2-(2-nitrophenyl)imidazo[1,2-a]pyridin-3-amine} $(7)^{50,53}$

CAS 2025389-47-1; yellow solid; mp 160-162 ${ }^{\circ} \mathrm{C}$ (lit: $\left.156-159^{\circ} \mathrm{C}\right) ;{ }^{50} \mathrm{H} \mathrm{NMR}\left(300 \mathrm{MHz}, \mathrm{CDCl}_{3}\right) \delta 0.95(\mathrm{~s}, 9 \mathrm{H})$, 2.74 (br s, H-NH), 6.81 (t, J 6.8 Hz, 1H), 7.13-7.27 (m, $1 \mathrm{H}), 7.45-7.58(\mathrm{~m}, 2 \mathrm{H}), 7.66(\mathrm{t}, J 7.5 \mathrm{~Hz}, 1 \mathrm{H}), 7.82(\mathrm{~d}$, $J 8.8 \mathrm{~Hz}, 1 \mathrm{H}), 7.92(\mathrm{~d}, J 8.0 \mathrm{~Hz}, 1 \mathrm{H}), 8.19$ (d, $J 6.8 \mathrm{~Hz}$, $1 \mathrm{H}) ;{ }^{13} \mathrm{C}$ NMR $\left(75 \mathrm{MHz}, \mathrm{CDCl}_{3}\right) \delta 30.0,55.6,111.8$, 117.6, 123.3, 124.2, 124.5, 124.7, 128.4, 130.1, 132.4, 132.8, 136.0, 142.3, 149.4; HRMS (pESI) $\mathrm{m} / \mathrm{z}$, calcd. for $\mathrm{C}_{17} \mathrm{H}_{19} \mathrm{~N}_{4} \mathrm{O}_{2}[\mathrm{M}]^{+}:$311.1503, found: 311.1477 .

\section{N-tert-Butyl-2-(3-nitrophenyl)imidazo[1,2-a]pyridin-3-amine} $(8)^{32}$

CAS 1171753-50-6; yellow solid; mp 167-170 ${ }^{\circ} \mathrm{C}$; ${ }^{1} \mathrm{H}$ NMR $\left(300 \mathrm{MHz}, \mathrm{CDCl}_{3}\right) \delta 1.10(\mathrm{~s}, 9 \mathrm{H}), 3.05$ (br s, $\mathrm{H}-\mathrm{NH}), 6.83(\mathrm{td}, J 6.8,1.1 \mathrm{~Hz}, 1 \mathrm{H}), 7.19$ (ddd, $J$ 9.0, 6.8, $1.1 \mathrm{~Hz}, 1 \mathrm{H}), 7.54-7.61(\mathrm{~m}, 2 \mathrm{H}), 8.14$ (ddd, $J 8.3$, $2.3,1.1 \mathrm{~Hz}, 1 \mathrm{H}), 8.20(\mathrm{dt}, J 6.8,1.1 \mathrm{~Hz}, 1 \mathrm{H}), 8.44$ (ddd, $J$ 7.7, $1.5,1.1 \mathrm{~Hz}, 1 \mathrm{H}), 9.02(\mathrm{t}, J 1.9 \mathrm{~Hz}, 1 \mathrm{H}) ;{ }^{13} \mathrm{C} \mathrm{NMR}$ $\left(75 \mathrm{MHz}, \mathrm{CDCl}_{3}\right) \delta 30.5,56.6,111.9,117.6,121.9,122.6$, 123.3, 124.0, 124.8, 129.1, 133.7, 136.9, 137.0, 142.4, 148.2; HRMS (pESI) $m / z$, calcd. for $\mathrm{C}_{17} \mathrm{H}_{19} \mathrm{~N}_{4} \mathrm{O}_{2}{ }^{+}[\mathrm{M}+\mathrm{H}]^{+}$: 311.1503, found: 311.1501 .

N-tert-Butyl-2-(4-chloro-3-nitrophenyl)imidazo[1,2-a]pyridin3-amine (9)

Yellow solid; mp 130-135 ${ }^{\circ} \mathrm{C}$; ${ }^{1} \mathrm{H}$ NMR $(300 \mathrm{MHz}$, $\left.\mathrm{CDCl}_{3}\right) \delta 1.14$ (s, 9H), 2.93 (br s, H-NH), 6.83 (td, J 6.8, $1.1 \mathrm{~Hz}, 1 \mathrm{H}), 7.20$ (ddd, $J 9.0,6.8,1.1 \mathrm{~Hz}, 1 \mathrm{H}), 7.52-7.58$ $(\mathrm{m}, 2 \mathrm{H}), 8.15(\mathrm{dt}, J 6.8,1.1 \mathrm{~Hz}, 1 \mathrm{H}), 8.30(\mathrm{dd}, J 8.4,2.0 \mathrm{~Hz}$, $1 \mathrm{H}), 8.78(\mathrm{~d}, J 2.0 \mathrm{~Hz}, 1 \mathrm{H}) ;{ }^{13} \mathrm{C}$ NMR $\left(75 \mathrm{MHz}, \mathrm{CDCl}_{3}\right)$ $\delta 22.9,30.6,58.7,112.1,117.7,123.2,124.1,124.5,125.0$, 125.1, 131.6, 132.0, 135.4, 136.0, 142.4, 147.7; HRMS
(pESI) $m / z$, calcd. for $\mathrm{C}_{17} \mathrm{H}_{18} \mathrm{ClN}_{4} \mathrm{O}_{2}{ }^{+}[\mathrm{M}+\mathrm{H}]^{+}$: 345.1113, found: 345.1114 .

N-tert-Butyl-2-(furan-2-yl)imidazo[1,2-a]pyridin-3-amine (10) $)^{36,37}$

CAS 943633-38-3; yellowish solid; mp 98-101 ${ }^{\circ} \mathrm{C}$; ${ }^{1} \mathrm{H}$ NMR (300 MHz, $\left.\mathrm{CDCl}_{3}\right) \delta 1.15$ (s, 9H), 3.55 (br s, $\mathrm{H}-\mathrm{NH}), 6.49-6.55(\mathrm{~m}, 1 \mathrm{H}), 6.80$ (t, $J 6.8 \mathrm{~Hz}, 1 \mathrm{H}), 6.99$ (d, J 3.1 Hz, 1H), 7.17 (t, J 7.9 Hz, 1H), 7.5 (br s, 1H), $7.57(\mathrm{~d}, J 9.0 \mathrm{~Hz}, 1 \mathrm{H}), 8.27$ (d, $J 6.8 \mathrm{~Hz}, 1 \mathrm{H}) ;{ }^{13} \mathrm{C} \mathrm{NMR}$ $\left(75 \mathrm{MHz}, \mathrm{CDCl}_{3}\right) \delta 29.9,56.4,108.0,111.7,111.8,116.6$, 123.8, 124.1, 125.2, 129.6, 141.5, 141.7, 149.4; HRMS (pESI) $m / z$, calcd. for $\mathrm{C}_{15} \mathrm{H}_{18} \mathrm{~N}_{3} \mathrm{O}^{+}[\mathrm{M}+\mathrm{H}]^{+}: 256.1444$, found: 256.1447 .

$N$-tert-Butyl-6-methyl-2-phenylimidazo[1,2-a]pyridin3-amine (11) $)^{71-73}$

CAS 334905-16-7; white solid; mp 215-217 ${ }^{\circ} \mathrm{C}$ (lit: $\left.216-219^{\circ} \mathrm{C}\right) ;{ }^{72}{ }^{1} \mathrm{H}$ NMR $\left(300 \mathrm{MHz}, \mathrm{CDCl}_{3}\right) \delta 0.95(\mathrm{~s}, 9 \mathrm{H})$, 2.26 (s, 3H), 2.34 (br s, H-NH), 6.90 (dd, J 9.2, $1.3 \mathrm{~Hz}, 1 \mathrm{H}$ ), 7.20-7.24 (m, 1H), 7.31-7.38 (m, 3H), 7.80 (d, J 7.5 Hz, 2H), 7.91 (s, $1 \mathrm{H}$ ); ${ }^{13} \mathrm{C} \mathrm{NMR}\left(75 \mathrm{MHz}, \mathrm{CDCl}_{3}\right.$ ) $\delta 18.4,30.2$, 56.3, 118.5, 120.8, 121.0, 123.2, 127.1, 127.2, 128.0, 128.2, 135.3, 139.2, 141.0; HRMS (pESI) $\mathrm{m} / z$, calcd. for $\mathrm{C}_{18} \mathrm{H}_{22} \mathrm{~N}_{3}{ }^{+}$ $[\mathrm{M}+\mathrm{H}]^{+}: 280.1808$, found: 280.1841 .

N-tert-Butyl-2-propylimidazo[1,2-a]pyridin-3-amine (12) ${ }^{37,66}$

CAS 1155257-79-6; white solid; mp $132-133{ }^{\circ} \mathrm{C}$ (lit: 129-130 $\left.{ }^{\circ} \mathrm{C}\right) ; 66{ }^{1} \mathrm{H}$ NMR $\left(300 \mathrm{MHz}, \mathrm{CDCl}_{3}\right) \delta 0.98(\mathrm{t}$, $J 7.4 \mathrm{~Hz}, 3 \mathrm{H}$ ), 1.18 (s, 9H), 1.82 (sext, $J 7.4 \mathrm{~Hz}, 2 \mathrm{H}$ ), 2.68-2.73 (m, 2H, NH), $6.72(\mathrm{t}, J 6.8 \mathrm{~Hz}, 1 \mathrm{H}), 7.03-7.13$ (m, 1H), $7.47(\mathrm{~d}, J 9.0 \mathrm{~Hz}, 1 \mathrm{H}), 8.15(\mathrm{~d}, J 6.8 \mathrm{~Hz}, 1 \mathrm{H})$; ${ }^{13} \mathrm{C}$ NMR $\left(75 \mathrm{MHz}, \mathrm{CDCl}_{3}\right) \delta 14.3,22.6,29.6,30.3,55.4$, 111.0, 116.4, 123.2, 123.6, 140.7, 141.6; HRMS (pESI) $\mathrm{m} / \mathrm{z}$, calcd. for $\mathrm{C}_{14} \mathrm{H}_{22} \mathrm{~N}_{3}{ }^{+}[\mathrm{M}+\mathrm{H}]^{+}:$232.1808, found: 232.1810 .

$N$-tert-Butyl-2-isopropylimidazo[1,2-a]pyridin-3-amine (13) 36,74

CAS 552855-93-3; white solid; mp $138-140{ }^{\circ} \mathrm{C}$; ${ }^{1} \mathrm{H}$ NMR $\left(300 \mathrm{MHz}, \mathrm{CDCl}_{3}\right) \delta 1.20(\mathrm{~s}, 9 \mathrm{H}), 1.35(\mathrm{~d}$, $J 6.8 \mathrm{~Hz}, 6 \mathrm{H}$ ), 2.70 (br s, H-NH), 3.16 (sept, $J 6.8 \mathrm{~Hz}, 1 \mathrm{H}$ ), $6.68(\mathrm{td}, J 6.8,1.1 \mathrm{~Hz}, 1 \mathrm{H}), 7.05(\mathrm{ddd}, J 9.0,6.8,1.1 \mathrm{~Hz}$, $1 \mathrm{H}), 7.48(\mathrm{~d}, J 9.0 \mathrm{~Hz}, 1 \mathrm{H}), 8.14(\mathrm{dt}, J 6.8,11 \mathrm{~Hz}, 1 \mathrm{H})$; ${ }^{13} \mathrm{C}$ NMR $\left(75 \mathrm{MHz}, \mathrm{CDCl}_{3}\right) \delta 22.9,25.9,30.3,55.1,110.6$, 116.9, 121.6, 123.0, 123.3, 142.1, 146.6; HRMS (pESI) $\mathrm{m} / z$, calcd. for $\mathrm{C}_{14} \mathrm{H}_{22} \mathrm{~N}_{3}{ }^{+}[\mathrm{M}+\mathrm{H}]^{+}$: 232.1808, found: 232.1808 .

$\mathrm{N}$-Cyclohexyl-2-phenylimidazo[1,2-a]pyridin-3-amine (14) $)^{68,75,76}$

CAS 214531-48-3; white solid; mp 177-179 ${ }^{\circ} \mathrm{C}$ (lit: $\left.178-180{ }^{\circ} \mathrm{C}\right) ;{ }^{75}{ }^{1} \mathrm{H}$ NMR $\left(500 \mathrm{MHz}, \mathrm{CDCl}_{3}\right) \delta$ 1.12-1.29 
(m, 5H), 1.51-1.87 (m, 5H), 2.93-2.98 (m, 1H), 3.36 (br s, H-NH), $6.82(\mathrm{t}, J 6.6 \mathrm{~Hz}, 1 \mathrm{H}), 7.17(\mathrm{t}, J 7.8 \mathrm{~Hz}, 1 \mathrm{H})$, 7.30-7.33 (m, 1H), $7.44(\mathrm{t}, J 7.8 \mathrm{~Hz}, 2 \mathrm{H}), 7.26(\mathrm{~d}, J 9.1 \mathrm{~Hz}$, $1 \mathrm{H}), 8.05(\mathrm{~d}, J 7.3 \mathrm{~Hz}, 2 \mathrm{H}), 8.16(\mathrm{~d}, J 6.6 \mathrm{~Hz}, 1 \mathrm{H}) ;{ }^{13} \mathrm{C} \mathrm{NMR}$ $\left(75 \mathrm{MHz}, \mathrm{CDCl}_{3}\right) \delta 24.8,25.7,34.1,56.9,111.4,117.4$, 122.7, 123.7, 124.9, 127.0, 127.2, 128.5, 134.6, 136.6, 141.6; HRMS (pESI) $\mathrm{m} / z$, calcd. for $\mathrm{C}_{19} \mathrm{H}_{22} \mathrm{~N}_{3}{ }^{+}[\mathrm{M}+\mathrm{H}]^{+}$: 292.1808, found: 292.1810 .

$\mathrm{N}$-Cyclohexyl-2-(4-nitrophenyl)imidazo[1,2-a]pyridin3-amine (15) $)^{50,72}$

CAS 1218933-47-1; yellow/orange solid; mp 232-234 ${ }^{\circ} \mathrm{C}$ (lit: $\left.235-237^{\circ} \mathrm{C}\right) ;{ }^{67,72}{ }^{1} \mathrm{H}$ NMR (300 MHz, $\left.\mathrm{CDCl}_{3}\right) \delta 1.07-1.38(\mathrm{~m}, 5 \mathrm{H}), 1.48-1.93(\mathrm{~m}, 5 \mathrm{H}), 2.90-3.04$ (m, 1H), 3.20 (br s, H-NH), 6.85 (t, J $6.8 \mathrm{~Hz}, 1 \mathrm{H}), 7.21$ $(\mathrm{t}, J 7.5 \mathrm{~Hz}, 1 \mathrm{H}), 7.57(\mathrm{~d}, J 9.0 \mathrm{~Hz}, 1 \mathrm{H}), 8.08(\mathrm{~d}, J 6.8 \mathrm{~Hz}$, $1 \mathrm{H}), 8.25-8.34(\mathrm{~m}, 4 \mathrm{H}) ;{ }^{13} \mathrm{C}$ NMR $\left(75 \mathrm{MHz}, \mathrm{CDCl}_{3}\right) \delta$ 24.8, 25.6, 34.2, 57.0, 112.4, 117.6, 122.4, 123.8, 125.2, 126.6, 127.2, 133.9, 140.7, 141.8, 146.5; HRMS (pESI) $m / z$, calcd. for $\mathrm{C}_{19} \mathrm{H}_{21} \mathrm{~N}_{4} \mathrm{O}_{2}{ }^{+}[\mathrm{M}+\mathrm{H}]^{+}: 337.1659$, found: 337.1671 .

$N$-Cyclohexyl-2-(3-nitrophenyl)imidazo[1,2-a]pyridin3-amine $(16)^{34}$

CAS 857298-24-9; yellow solid; mp 196-198 ${ }^{\circ} \mathrm{C}$ (lit: $\left.198-200^{\circ} \mathrm{C}\right) ;{ }^{34}{ }^{1} \mathrm{H} \mathrm{NMR}\left(300 \mathrm{MHz}, \mathrm{CDCl}_{3}\right) \delta 1.09-1.40(\mathrm{~m}$, $5 \mathrm{H}), 1.59-1.97(\mathrm{~m}, 5 \mathrm{H}), 2.92-3.14(\mathrm{~m}, 1 \mathrm{H}, \mathrm{H}-\mathrm{NH}), 6.83$ (t, $J 6.8 \mathrm{~Hz}, 1 \mathrm{H}), 7.15-7.23(\mathrm{~m}, 1 \mathrm{H}), 7.54-7.63(\mathrm{~m}, 2 \mathrm{H})$, 8.08-8.16 (m, 2H), $8.51(\mathrm{~d}, J 7.7 \mathrm{~Hz}, 1 \mathrm{H}), 9.06(\mathrm{t}, J 1.7 \mathrm{~Hz}$, $1 \mathrm{H}) ;{ }^{13} \mathrm{C}$ NMR $\left(75 \mathrm{MHz}, \mathrm{CDCl}_{3}\right) \delta 24.8,25.6,34.3,57.2$, $112.1,117.7,121.5,121.7,122.7,124.7,125.6,129.3$, 132.7, 134.4, 136.3, 141.9, 148.5; HRMS (pESI) $\mathrm{m} / 2$, calcd. for $\mathrm{C}_{19} \mathrm{H}_{21} \mathrm{~N}_{4} \mathrm{O}_{2}{ }^{+}[\mathrm{M}+\mathrm{H}]^{+}:$337.1659, found: 337.1663.

\section{N-Cyclohexyl-2-propylimidazo[1,2-a]pyridin-3-amine (17)}

CAS 858909-77-0; white solid; mp 74-77 ${ }^{\circ} \mathrm{C}$; ${ }^{1} \mathrm{H}$ NMR $\left(500 \mathrm{MHz}, \mathrm{CDCl}_{3}\right) \delta 0.99(\mathrm{t}, J 7.3 \mathrm{~Hz}, 1 \mathrm{H}), 1.17-1.28(\mathrm{~m}$, $5 \mathrm{H}), 1.60-1.88(\mathrm{~m}, 7 \mathrm{H}), 2.69-2.72(\mathrm{~m}, 2 \mathrm{H}), 2.81-2.90(\mathrm{~m}$, $1 \mathrm{H}, \mathrm{H}-\mathrm{NH}), 6.77$ (td, $J 6.8,1.2 \mathrm{~Hz}, 1 \mathrm{H}), 7.11$ (ddd, $J$ 9.0, $6.8,1.2 \mathrm{~Hz}, 1 \mathrm{H}), 7.50(\mathrm{dt}, J 9.0,1.2 \mathrm{~Hz}, 1 \mathrm{H}), 8.05(\mathrm{dt}, J 6.8$, $1.2 \mathrm{~Hz}, 1 \mathrm{H}) ;{ }^{13} \mathrm{C}$ NMR $\left(125 \mathrm{MHz}, \mathrm{CDCl}_{3}\right) \delta 14.2,22.7$, 24.8, 25.7, 29.0, 34.2, 57.2, 111.4, 116.4, 122.5, 123.6, 124.7, 138.6, 140.9; HRMS (pESI) $\mathrm{m} / z$, calcd. for $\mathrm{C}_{16} \mathrm{H}_{24} \mathrm{~N}_{3}{ }^{+}$ $[\mathrm{M}+\mathrm{H}]^{+}:$258.1965, found: 258.1972 .

$\mathrm{N}$-Cyclohexyl-2-isopropylimidazo[1,2-a]pyridin-3-amine $(\mathbf{1 8})^{77}$

CAS 484692-11-7; white solid; mp $114-116^{\circ} \mathrm{C}$ (lit: $\left.116-118{ }^{\circ} \mathrm{C}\right) ; 7^{77} \mathrm{H}$ NMR $\left(300 \mathrm{MHz}, \mathrm{CDCl}_{3}\right) \delta 1.18-1.34$ $(\mathrm{m}, 5 \mathrm{H}), 1.38(\mathrm{~d}, J 6.8 \mathrm{~Hz}, 6 \mathrm{H}), 1.55-1.94(\mathrm{~m}, 5 \mathrm{H}), 2.86$ (br s, H-NH), 3.16 (sept, $J 6.8 \mathrm{~Hz}, 1 \mathrm{H}), 6.79$ (t, $J 6.8 \mathrm{~Hz}$,
1H), 7.09-7.18 (m, 1H), 7.60 (d, J 9.0 Hz, 1H), 8.07 (d, $J 6.8 \mathrm{~Hz}, 1 \mathrm{H}) ;{ }^{13} \mathrm{C}$ NMR $\left(75 \mathrm{MHz}, \mathrm{CDCl}_{3}\right) \delta 22.7,24.9$, 25.7, 25.9, 34.2, 57.2, 111.7, 116.4, 122.6, 123.2, 124.0, 140.7, 143.4; HRMS (pESI) $\mathrm{m} / \mathrm{z}$, calcd. for $\mathrm{C}_{16} \mathrm{H}_{24} \mathrm{~N}_{3}{ }^{+}$ $[\mathrm{M}+\mathrm{H}]^{+}:$258.1965, found: 258.1972 .

N-tert-Butyl-6-phenylimidazo[2,1-b]thiazol-5-amine (19),

CAS 214531-41-6; yellowish solid; mp 151-154 ${ }^{\circ} \mathrm{C}$ (lit: $\left.150-152{ }^{\circ} \mathrm{C}\right) ;{ }^{50}{ }^{1} \mathrm{H}$ NMR $\left(300 \mathrm{MHz}, \mathrm{CDCl}_{3}\right) \delta 0.99$ (s, 9H), $6.66(\mathrm{~d}, J 4.6 \mathrm{~Hz}, 1 \mathrm{H}), 7.16-7.20(\mathrm{~m}, 1 \mathrm{H}), 7.28-7.34$ $(\mathrm{m}, 3 \mathrm{H}), 7.81(\mathrm{~d}, J 7.4 \mathrm{~Hz}, 2 \mathrm{H}) ;{ }^{13} \mathrm{C}$ NMR $(75 \mathrm{MHz}$, $\left.\mathrm{CDCl}_{3}\right) \delta 30.2,55.8,111.5,117.8,125.5,126.8,127.2$, 128.2, 135.1, 140.0, 145.5; HRMS (pESI) $\mathrm{m} / \mathrm{z}$, calcd. for $\mathrm{C}_{15} \mathrm{H}_{18} \mathrm{~N}_{3} \mathrm{~S}^{+}[\mathrm{M}+\mathrm{H}]^{+}:$272.1216, found: 272.1212 .

N-tert-Butyl-6-(4-nitrophenyl)imidazo[2,1-b]thiazol-5-amine (20)

Yellow solid; mp 190-192 ${ }^{\circ} \mathrm{C}$; ${ }^{1} \mathrm{H}$ NMR $(300 \mathrm{MHz}$, $\left.\mathrm{CDCl}_{3}\right) \delta 1.13(\mathrm{~s}, 9 \mathrm{H}), 2.93(\mathrm{br} \mathrm{s}, \mathrm{NH}), 6.82(\mathrm{~d}, J 4.2 \mathrm{~Hz}$, $1 \mathrm{H}), 7.39$ (d, $J 4.2 \mathrm{~Hz}, 1 \mathrm{H}), 8.19-8.29(\mathrm{~m}, 4 \mathrm{H}) ;{ }^{13} \mathrm{C} \mathrm{NMR}$ $\left(75 \mathrm{MHz}, \mathrm{CDCl}_{3}\right) \delta 30.3,56.3,112.7,117.6,123.6,127.0$, 127.2, 138.1, 141.9, 146.0, 146.7; HRMS (pESI) $\mathrm{m} / z$, calcd. for $\mathrm{C}_{15} \mathrm{H}_{17} \mathrm{~N}_{4} \mathrm{O}_{2} \mathrm{~S}^{+}[\mathrm{M}+\mathrm{H}]^{+}$: 317.1067 , found: 317.1064 .

$N$-tert-Butyl-6-(4-methoxyphenyl)imidazo[2,1-b]thiazol5-amine (21)

Brownish solid; mp 130-132 ${ }^{\circ} \mathrm{C} ;{ }^{1} \mathrm{H}$ NMR $(300 \mathrm{MHz}$, $\left.\mathrm{CDCl}_{3}\right) \delta 1.06$ (s, 9H), 2.97 (br s, $\left.\mathrm{H}-\mathrm{NH}\right), 3.83(\mathrm{~s}, 3 \mathrm{H})$, $6.70(\mathrm{~d}, J 4.5 \mathrm{~Hz}, 1 \mathrm{H}), 6.92(\mathrm{~d}, J 8.9 \mathrm{~Hz}, 2 \mathrm{H}), 7.35(\mathrm{~d}$, $J 4.5 \mathrm{~Hz}, 1 \mathrm{H}), 7.82(\mathrm{~d}, J 8.9 \mathrm{~Hz}, 2 \mathrm{H}) ;{ }^{13} \mathrm{C}$ NMR $(75 \mathrm{MHz}$, $\left.\mathrm{CDCl}_{3}\right) \delta 30.2,55.2,55.6,111.1,113.5,117.8,124.7,127.9$, $128.4,139.9,145.2,158.4$; HRMS (pESI) $\mathrm{m} / 2$, calcd. for $\mathrm{C}_{16} \mathrm{H}_{20} \mathrm{~N}_{3} \mathrm{OS}^{+}[\mathrm{M}+\mathrm{H}]^{+}:$302.1322, found: 302.1328 .

\section{N-tert-Butyl-6-propylimidazo[2,1-b]thiazol-5-amine (22)}

White solid; mp 100-103 ${ }^{\circ} \mathrm{C}$; ${ }^{1} \mathrm{H}$ NMR $(300 \mathrm{MHz}$, $\left.\mathrm{CDCl}_{3}\right) \delta 0.90(\mathrm{t}, J 7.4 \mathrm{~Hz}, 3 \mathrm{H}), 1.10(\mathrm{~s}, 9 \mathrm{H}), 1.68$ (sext, $J 7.4 \mathrm{~Hz}, 2 \mathrm{H}), 2.47$ (t, $J 7.4 \mathrm{~Hz}, 2 \mathrm{H}), 2.65$ (br s, H-NH), $6.58(\mathrm{~d}, J 4.4 \mathrm{~Hz}, 1 \mathrm{H}), 7.22(\mathrm{~d}, J 4.4 \mathrm{~Hz}, 1 \mathrm{H}) ;{ }^{13} \mathrm{C} \mathrm{NMR}$ $\left(75 \mathrm{MHz}, \mathrm{CDCl}_{3}\right) \delta 14.2,22.6,29.7,30.1,54.7,110.3$, 117.7, 125.1, 141.5, 144.7; HRMS (pESI) $\mathrm{m} / z$, calcd. for $\mathrm{C}_{12} \mathrm{H}_{20} \mathrm{~N}_{3} \mathrm{~S}^{+}[\mathrm{M}+\mathrm{H}]^{+}:$238.1372, found: 238.1381 .

N-tert-Butyl-6-isopropylimidazo[2,1-b]thiazol-5-amine (23)

White solid; mp 146-149 ${ }^{\circ} \mathrm{C}$; ${ }^{1} \mathrm{H}$ NMR $(300 \mathrm{MHz}$, $\left.\mathrm{CDCl}_{3}\right) \delta 1.19(\mathrm{~s}, 9 \mathrm{H}), 1.21$ (d, J 6.8 Hz, 6H), 2.64 (br s, H-NH), 2.90 (sept, J $6.8 \mathrm{~Hz}$ ), 6.57 (d, J 4.5 Hz, 1H), 7.22 $(\mathrm{d}, J 4.4 \mathrm{~Hz}, 1 \mathrm{H}) ;{ }^{13} \mathrm{C}$ NMR $\left(75 \mathrm{MHz}, \mathrm{CDCl}_{3}\right) \delta 22.9$, 26.1, 30.2, 54.3, 110.3, 117.7, 123.5, 145.0, 146.9; HRMS (pESI) $\mathrm{m} / z$, calcd. for $\mathrm{C}_{12} \mathrm{H}_{20} \mathrm{~N}_{3} \mathrm{~S}^{+}[\mathrm{M}+\mathrm{H}]^{+}: 238.1379$, found: 238.1381 . 


\section{Supplementary Information}

Supplementary information is available free of charge at http://jbcs.sbq.org.br as PDF file.

\section{Acknowledgments}

The authors gratefully acknowledge funding and student fellowships from FAPESP (2015/11155-0, 2017/06628-2 and 2019/01314-5) as well as CNPq (UNIFESP PIBITI/ PIBIC Program). Luiz S. Longo Jr. is also grateful to Prof Peter Licence and Dr Ana Santos for helpful discussions and access to The University of Nottingham analytical services.

\section{Author Contributions}

Gabriela F. D. Santos and Nicolas S. Anjos took major responsibility for investigation, methodology, formal analysis and writing (review and editing). Miguel M. Gibeli, Guilherme A. Silva, Pamela C. S. Fernandes and Everton S. C. Fiorentino individually contributed with investigation and methodology, as well as partial formal analysis. Luiz S. Longo Jr. was responsible for conceptualization, fund acquisition, project administration, supervision, visualization and writing (draft, review and editing).

\section{References}

1. Galloway, W. R. J. D.; Isidro-llobet, A.; Spring, D. R.; Nat. Commun. 2010, 1, DOI: 10.1038/ncomms1081.

2. Connor, C. J. O.; Beckmann, S. G.; Spring, D. R.; Connor, C. C. O.; Chem. Soc. Rev. 2012, 41, 4444.

3. Biggs-houck, J. E.; Younai, A.; Shaw, J. T.; Curr. Opin. Chem. Biol. 2010, 14, 371.

4. Ruijter, E.; Scheffelaar, R.; Orru, R. V. A.; Angew. Chem., Int. Ed. 2011, 50, 6234.

5. Brauch, S.; van Berkel, S. S.; Westermann, B.; Chem. Soc. Rev. 2013, 42, 4948.

6. Cioc, R. C.; Ruijter, E.; Orru, R. V. A.; Green Chem. 2014, 16, 2958.

7. Groebke, K.; Weber, L.; Mehlin, F.; Synlett 1998, 661.

8. Bienaymé, H.; Bouzid, K.; Angew. Chem., Int. Ed. 1998, 37, 2234.

9. Blackburn, C.; Guan, B.; Fleming, P.; Shiosaki, K.; Tsai, S.; Tetrahedron Lett. 1998, 39, 3635.

10. Blackburn, C.; Tetrahedron Lett. 1998, 39, 5469.

11. Kaur, T.; Wadhwa, P.; Bagchi, S.; Sharma, A.; Chem. Commun. 2016, 52, 6958.

12. Abdel-wahab, S. S. B. F.; Mol. Diversity 2016, 20, 233.

13. Liu, Z.-Q.; Mini.-Rev. Org. Chem. 2016, 13, 166.
14. Devi, N.; Rawal, R. K.; Singh, V.; Tetrahedron 2015, 71, 183.

15. Boltjes, A.; Dömling, A.; Eur. J. Org. Chem. 2019, 7007.

16. Pericherla, K.; Kaswan, P.; Pandey, K.; Kumar, A.; Synthesis 2015, 47, 887.

17. Bagdi, A. K.; Santra, S.; Monir, K.; Hajra, A.; Chem. Commun. 2015, 51, 1555.

18. Tber, Z.; Hiebel, M.-A.; El Hakmaoui, A.; Akssira, M.; Guillaumet, G.; Berteina-Raboin, S.; J. Org. Chem. 2015, 80, 6564.

19. Arnould, M.; Hiebel, M.-A.; Massip, S.; Léger, J. M.; Jarry, C.; Berteina-Raboin, S.; Guillaumet, G.; Chem. - Eur. J. 2013, 19, 12249.

20. Huang, Y.; Hu, X.-Q.; Shen, D.-P.; Chen, Y.-F.; Xu, P.-F.; Mol. Diversity 2007, 11, 73.

21. Shaabani, A.; Soleimani, E.; Maleki, A.; Rad, J. M.; Synth. Commun. 2008, 38, 1090.

22. Polyakov, A. I.; Eryomina, V. A.; Medvedeva, L. A.; Tihonova, N. I.; Voskressensky, L. G.; J. Heterocycl. Chem. 2008, 45, 1589.

23. Shukla, N. M.; Salunke, D. B.; Yoo, E.; Mutz, C. A.; Balakrishna, R.; David, S. A.; Bioorg. Med. Chem. 2012, 20, 5850.

24. Salunke, D. B.; Yoo, E.; Shukla, N. M.; Balakrishna, R.; Malladi, S. S.; Sera, K. J.; Day, V. W.; Wang, X.; David, S. A.; J. Med. Chem. 2012, 55, 8137.

25. Shaabani, A.; Soleimani, E.; Maleki, A.; Monatsh. Chem. 2007, 138,73 .

26. Shinde, V. V.; Jung, S.; Tetrahedron 2019, 75, 778.

27. Rostami, M. E.; Gorji, B.; Zadmard, R.; Tetrahedron Lett. 2018 , 59,6 .

28. Shaabani, A.; Seyyedhamzeh, M.; Shaabani, S.; Ganji, N.; Res. Chem. Intermed. 2013, 41, 2377.

29. Shaabani, A.; Nosrati, H.; Seyyedhamzeh, M.; Res. Chem. Intermed. 2015, 41, 3719.

30. Jafarzadeh, M.; Soleimani, E.; Sepahvand, H.; Adnan, R.; RSC Adv. 2015, 5, 42744.

31. Kishore, K. G.; Basavanag, U. M. V.; Islas-jácome, A.; Gámez-Montaño, R.; Tetrahedron Lett. 2015, 56, 155.

32. Shahrisa, A.; Esmati, S.; Synlett 2013, 595.

33. Shahrisa, A.; Safa, K. D.; Esmati, S.; Spectrochim. Acta, Part A 2014, 117, 614.

34. Rostamnia, S.; Hassankhani, A.; RSC Adv. 2013, 3, 18626.

35. Santra, S.; Mitra, S.; Bagdi, A. K.; Majee, A.; Hajra, A.; Tetrahedron Lett. 2014, 55, 5151.

36. Rousseau, A. L.; Matlaba, P.; Parkinson, C. J.; Tetrahedron Lett. 2007, 48, 4079.

37. Guchhait, K.; Madaan, C.; Synlett 2009, 628.

38. Guchhait, S. K.; Madaan, C.; Thakkar, B. S.; Synthesis 2009 , 3293.

39. Zhang, Z.; Xu, L.; Tang, H.; Wu, B.; Feng, D.; Guo, C.; Chinese J. Org. Chem. 2017, 37, 1252.

40. Shinde, A. H.; Srilaxmi, M.; Satpathi, B.; Sharada, D. S.; Tetrahedron 2014, 55, 5915. 
41. Kobayashi, S.; Sugiura, M.; Kitagawa, H.; Lam, W. W.-L.; Chem. Rev. 2002, 102, 2227.

42. Kobayashi, S.; Manabe, K.; Acc. Chem. Res. 2002, 35, 209.

43. Ladziata, U. V.; ARKIVOC 2014, 2014, 307.

44. Al-tel, T. H.; Al-qawasmeh, R. A.; Voelter, W.; Eur. J. Org. Chem. 2010, 5586.

45. Maiti, B.; Chanda, K.; Selvaraju, M.; Tseng, C.; Sun, C.; ACS Comb. Sci. 2013, 15, 291.

46. Lu, Y.; Zhang, W.; QSAR Comb. Sci. 2004, 23, 827.

47. Ireland, S. M.; Tye, H.; Whittaker, M.; Tetrahedron Lett. 2003 , $44,4369$.

48. Agrebi, A.; Allouche, F.; Chabchoub, F.; El-Kaim, L.; Alves, S.; Baleizão, C.; Farinha, J. P.; Tetrahedron Lett. 2013, 54, 4781.

49. Ren, J.; Yang, M.; Liu, H.; Cao, D.; Chen, D.; Li, J.; Tang, L.; He, J.; Chen, Y.-L.; Geng, M.; Xiong, B.; Shen, J.; Org. Biomol. Chem. 2015, 13, 1531.

50. Ansari, A. J.; Sharma, S.; Pathare, R. S.; Gopal, K.; Sawant, D. M.; Pardasani, R. T.; ChemistrySelect 2016, 5, 1016.

51. Zhou, H.; Wang, W.; Khorev, O.; Zhang, Y.; Miao, Z.; Meng, T.; Shen, J.; Eur. J. Org. Chem. 2012, 5585.

52. Devi, N.; Singh, D.; Kaur, G.; Mor, S.; Putta, V. P. R. K.; Polina, S.; Malakar, C. C.; Singh, V.; New J. Chem. 2017, 41, 1082.

53. Swami, S.; Agarwala, A.; Shrivastava, R.; Mol. Diversity 2017, 21,81 .

54. Devi, N.; Singh, D.; Mor, S.; Chaudhary, S.; Rawal, R. K.; Kumar, V.; Chowdhury, A. K.; Singh, V.; RSC Adv. 2016, 6, 43881

55. Devi, N.; Singh, D.; Sunkaria, R. K.; Malakar, C. C.; Mehra, S.; Rawal, R. K.; Singh, V.; ChemistrySelect 2016, 1, 4696.

56. Kobayashi, S.; Hachiya, I.; J. Org. Chem. 1994, 59, 3590.

57. Lee, S. G.; Kim, S. G.; Tetrahedron 2018, 74, 3671.

58. Lee, S. G.; Sin, S.; Kim, S.; Kim, S. G.; Tetrahedron Lett. 2018, 59, 1480.

59. Murarka, S.; Zhang, C.; Konieczynska, M. D.; Seidel, D.; Org. Lett. 2009, 11, 129.

60. Tanaka, Y.; Kanai, M.; Shibasaki, M.; Synlett 2008, 2295.

61. Nguyen, V. T. A.; Duus, F.; Le, T. N.; Asian J. Org. Chem. 2014, 3,963 .

62. Tsuruta, H.; Yamaguchi, K.; Imamoto, T.; Tetrahedron 2003, 59,10419 .
63. Fortuna, C. G.; Musumarra, G.; Nardi, M.; Procopio, A.; Sindona, G.; Sciré, S.; J. Chemom. 2007, 20, 418.

64. Murlykina, M. V.; Kornet, M. N.; Desenko, S. M.; Shishkina, S. V.; Shishkin, O. V.; Brazhko, A. A.; Musatov, V. I.; Van Der Eycken, E. V.; Chebanov, V. A.; Beilstein J. Org. Chem. 2017, 13,1050 .

65. ACD/NMR Processor Academic Edition, version 12.01; ACD Labs, Toronto, 2010. Available at www.acdlabs.com/nmrproc/, accessed in February 2020.

66. Baviskar, A. T.; Madaan, C.; Preet, R.; Mohapatra, P.; Jain, V.; Agarwal, A.; Guchhait, S. K.; Kundu, C. N.; Banerjee, U. C.; Bharatam, P. V.; J. Med. Chem. 2011, 54, 5013.

67. Allahabadi, E.; Ebrahimi, S.; Soheilizad, M.; Khoshneviszadeh, M.; Tetrahedron Lett. 2017, 58, 121.

68. Vidyacharan, S.; Shinde, A. H.; Satpathi, B.; Sharada, D. S.; Green Chem. 2014, 16, 1168.

69. Reutlinger, M.; Rodrigues, T.; Schneider, P.; Schneider, G.; Angew. Chem., Int. Ed. 2014, 53, 582.

70. Habibi, A.; Tarameshloo, Z.; Rostamizadeh, S.; Amani, A. M.; Lett. Org. Chem. 2012, 2, 155.

71. Khan, A. T.; Basha, R. S.; Lal, M.; Tetrahedron Lett. 2012, 53, 2211.

72. Adib, M.; Sheikhi, E.; Rezaei, N.; Tetrahedron Lett. 2011, 52, 3191.

73. Shaabani, A.; Soleimani, E.; Maleki, A.; Tetrahedron Lett. 2006, 47, 3031 .

74. Krasavin, M.; Tsirulnikov, S.; Nikulnikov, M.; Sandulenko, Y.; Bukhryakov, K.; Tetrahedron Lett. 2008, 49, 7318.

75. Sanaeishoar, T.; Tavakkoli, H.; Mohave, F.; Appl. Catal., A 2014, 470, 56.

76. Azizi, N.; Dezfooli, S.; Environ. Chem. Lett. 2016, 14, 201.

77. Bode, M. L.; Gravestock, D.; Moleele, S. S.; Van Der Westhuyzen, C. W.; Pelly, S. C.; Steenkamp, P. A.; Hoppe, H. C.; Khan, T.; Nkabinde, L. A.; Bioorg. Med. Chem. 2011, 19, 4227.

Submitted: December 3, 2019 Published online: February 19, 2020 